$\underline{\text { Research Article }}$

\title{
Effectiveness of Motivational Interviewing on Self-Management of Type 2 Diabetes Mellitus Patients: A Systematic Review
}

\section{Efektivitas Motivational Interviewing terhadap Manajemen Diri Pasien Diabetes Mellitus Tipe 2: Sistematic Review}

\author{
Siska Puji L', Titin Andri $W^{2}$, Dina Dewi Sartika $L 1^{3}$ \\ ${ }^{1}$ Postgraduate Programme in Medical-surgical Nursing Faculty of Medicine Universitas Brawijaya Malang \\ ${ }^{2,3}$ Department of Nursing Faculty of Medicine Universitas Brawijaya Malang
}

\begin{abstract}
Diabetes mellitus is a health problem that will affect the health status of patients. Motivational interviewing a counseling technique focusing on clients and it is designed for helping individuals explore and accomplish ambivalence in behavior. This systematic review aimed at describing effectiveness motivational interviewing on self-management of diabetes mellitus type 2 patients. There are 1359 articles of 526 ScienceDirect articles, 422 ProQuest, 290 PubMed, and 121 Ebsco articles. The systematic review method began by identifying 20 articles from four electronic databases for previous studies that were published during 2011-2021. The results of the systematic review obtained that motivational interviewing can provide improved self-management and control blood glucose DM type 2 patients. The conclusion motivational interviewing can affect the patient's self-management especially on blood glucose profile, dietary compliance, quality of life, self-efficacy, HbA1c levels of DM type 2 patients.
\end{abstract}

Keywords: Motivational interviewing, self-management, type 2 Diabetes Mellitus

\section{ABSTRAK}

Diabetes melitus adalah suatu masalah kesehatan yang bisa mempengaruhi status kesehatan pasien. Motivational interviewing merupakan suatu motivasi yang berasal dari dalam diri pasien itu sendiri yang dirancang untuk membantu menyelesaikan masalah kepatuhan pasien. Sistematik review ini bertujuan menjelaskan efektivitas motivational interviewing pada manajemen diri pasien Diabetes Mellitus tipe 2. Metode sistematika review dimulai dengan mengidentifikasi artikel penelitian dari database PubMed, Science Direct, Ebsco, dan ProQuest yang diterbitkan tahun 2011-2021. Terdapat 1359 artikel yang terdiri dari 526 artikel ScienceDirect, 422 ProQuest, 290 PubMed,dan 121 artikel Ebsco. Artikel di seleksi menggunakan PRISMA dan mendapatkan 20 artikel yang membahas bahwa motivational interviewing dapat memberikan peningkatan manajemen diri dan mengontrol glukosa darah pasien DM tipe 2. Kesimpulannya motivational interviewing dapat mempengaruhi manajemen diri pasien terutama pada profil tekanan darah, kepatuhan diet, kualitas hidup, efikasi diri, dan kadar HbA1c pasien diabetes melitus tipe 2.

Kata Kunci: DM tipe 2, manajemen diri, motivational interviewing

Correspondence: Siska Puji L. Postgraduate Programme in Medical-surgical Nursing Faculty of Medecine Universitas Brawijaya, Jl. Veteran Tel.087856888820Email: siskapuji96@student.ub.ac.id

DOI: http://dx.doi.org/10.21776/ub.jkb.2021.031.04.11 


\section{INTRODUCTION}

Diabetes Mellitus is the most serious global health issue, and by the rising prevalence, it will affect the patients' morbidity and mortality and increase most healthcare costs. Diabetes patients deal with a new life, whereby the diabetes patients shall be able to organize their selfmanagement (1). The diabetes management that a sustainable experience of life for DM type 2 patients needs develop for application a self-management behavior to achieve the optimum result. In 2014 the International of Diabetes Federation (IDF) estimates that 387 a million of people, in the world lived with diabetes and 4.9 million of mortality happened due to diabetes mellitus (2). The center for Disease Control and Prevention (CDC) showed prevalence in the United States of America was 9.3\%. Around $90-95 \%$ of this case is diagnosed with diabetes mellitus. Poor self-management can cause complications for sufferers (3). Therefore, most diabetes mellitus patients have a risk of hyperlipidemia, hypertension, and macrovascular complications of diabetes. Diabetes treatment is associated with a far higher lifetime medical cost, especially when the patients' self-management and compliance are poor. The rising prevalence complications showed the need for an intervention that encourages a positive change of health behavior in self-management (4).

Self-management is the most important thing in controlling diabetes, yet some problems mentioned in several pieces of literature show that the level of selfmanagement patients is low. Low level of selfmanagement patients cause many factors, such as the factor of medication adherence (5). Diabetes mellitus patients tend to consider themselves having no symptoms, diabetes mellitus patients often do not perform a regular control in a healthcare facility. Moreover, diabetes mellitus patients do not consume medicine regularly since the patients do not know their blood glucose profile (6). One of the reasons for patients not consuming diabetes mellitus medicine is the boredom of taking anti-diabetes medicine. The low-level self-management will increase the complications. Compliance is required for diabetes mellitus patients. An increase in compliance is required for being motivated in treating the disease independently. The psychological condition can affect the regulation of the psychological process and facilitate the change in the behavior of type 2 DM patients (7).

There are 7 behaviors in diabetes management according to the American Association of Diabetes Educators (AADE) including healthy food, physical activity, compliance in treatment, monitoring glucose levels in the blood, monitoring problems in treatment, the decrease in the risk of severe and chronic complications, and healthy life (8). Other important self-care behaviors in diabetes patients are stop smoking, decreasing alcohol intake, foot check, etc. Several types of intervention used for supporting self-management of diabetes patients, including education up to the modification of the diabetes mellitus patients' behavior (9).

Motivational interviewing is one of the counseling techniques aiming at encouraging individuals to explore and discover the reasons inside them that have never come to their mind to change their behavior. Inappropriate behavior performed by patients can be from themselves or external factors. This behavior will give a big impact on patient behavior (10). Motivation-based intervention is expected to bring a change in patient management. Behavior given by implementing the principle of motivation is, for example, by motivational interviewing. The implementation of motivational interviewing is expected to be able to improve the patient behavior against the treatment since it builds an individual awareness of adhering to the medication principle that is based on oneself's willingness to recover (11).

The treatment guideline from American Diabetes Association (ADA) recommends patient-centered communication, this is an intervention recommendation that can change the behavior of diabetes mellitus patients. This behavior involves the intrinsic motivation that exists in the patient to change, so that the poor lifestyle of diabetes mellitus patients' compliance in managing selfmanagement can be improved (12). Therefore systematic review will describe the effectiveness of motivational interviewing.

\section{METHOD}

\section{Study Question}

First does motivational interviewing decrease glycosylated hemoglobin A1C (HbA1C) level? Secondly, does motivational interviewing intervention have an effect on improving self-management of people with type 2 diabetes mellitus? To answer research questions, the authors conducted a systematic review with quantitative data. Selection criteria for eligible studies and data extraction processes are performed using PICOS format and PRISMA guidelines.

\section{Type of Studies}

This sistematic review uses studies with randomized controlled clinical trials (RCT).

\section{Eligibility Criteria}

All globally conducted studies which are published between 2011 and 2021, peer reviewed, ethically approved, written in English only and full text were included in the review. All descriptive, case-report, qualitative studies, literature reviews, study protocols and conference abstracts were excluded from the review process and duplicates from different searches were removed.

\section{Type of Interventions}

The reviewed articles that used Motivational Interviewing (MI) as an intervention, delivered by trained professionals and targeted at Type 2 Diabetes Mellitus (T2DM) patients were clearly defined.

\section{Search Methods (Strategy) and Review Process}

The databases of ScienceDirect, Pubmed, ProQuest, and EBSCO. This literatures were reviewed for relevant studies based in the eligibility criteria. Key words and Mesh terms were used to search based on the PICOS model and included: "type 2 diabetes," "diabetes mellitus," "noninsulin dependent diabetes mellitus," "adult onset diabetes," "glycemic control," "glycosylated hemoglobin","HgbA1C", "self management," and "motivational interviewing". 
Table 1. Article selection criteria

\begin{tabular}{|c|c|c|}
\hline Point & Inclusion & Exception \\
\hline Respondents & Diabetes mellitus patient & $\begin{array}{l}\text { Non diabetes } \\
\text { mellitus patient }\end{array}$ \\
\hline Problem & $\begin{array}{l}\text { Self-management } \\
\text { compliance }\end{array}$ & $\begin{array}{l}\text { Non-self- } \\
\text { management role }\end{array}$ \\
\hline Checklists & No comparison & \\
\hline Results & $\begin{array}{l}\text { There is motivational } \\
\text { involvement in DM patient } \\
\text { compliance }\end{array}$ & $\begin{array}{l}\text { Not talking about } \\
\text { motivational } \\
\text { interviewing }\end{array}$ \\
\hline $\begin{array}{l}\text { Design Studies and } \\
\text { publication types }\end{array}$ & Quantitative research & Qualitative research \\
\hline Year of publication & Pasca-2011011 & $\operatorname{Pr} 2$ \\
\hline \multirow[t]{2}{*}{ Language ar } & agearglish & L other \\
\hline & & than English \\
\hline
\end{tabular}

\section{Selection of Studies}

All potentially relevant retrieved articles were investigated as full text. The inclusion and exclusion criteria for the papers included in the study were defined in the study protocol prior to commencing the review. Inclusion criteria (defined according to PICOS) were as follows: P: people with type 2 diabetes, I: Motivational Interviewing (MI) interventions, C: usual care or a nonMotivational Interviewing (MI) intervention, $\mathrm{O}$ : glycosylated hemoglobin A1C (HgbA1C) level and self management and S: randomized controlled trials (RCTs). The determination of inclusion and exclusion criteria was adjusted according to the objective of this systematic review. The inclusion criteria in this systematic review were studies focusing on diabetes mellitus patients as the population, studies discussing the relevancy between motivational interviewing and self-management in diabetes mellitus patients, and studies focusing on original research. Meanwhile, the exclusion criteria comprised qualitative studies, studies besides diabetes mellitus patients, and article review studies. The results of the study articles selection can be illustrated in the Flow Diagram using the PRISMA selection process below:

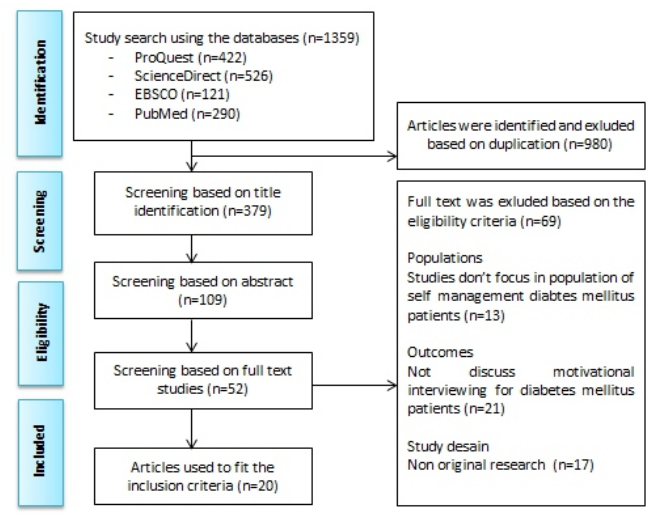

Figure 1. Flowchart of articles selected on the systematic review, selection process using PRISMA

\section{Assessment of Methodological Quality}

After the process of study selection, methodological quality of the studies was assessed using Joanna Briggs Institutes Critical Appraisal Checklists for randomized studies (Tables 2). Articles with more than average score were included in the review.
Table 2. Evaluation of the methodological quality of included studies (RCT)

\begin{tabular}{lccccccccccccc}
\hline First authors & $\mathbf{1}$ & $\mathbf{2}$ & $\mathbf{3}$ & $\mathbf{4}$ & $\mathbf{5}$ & $\mathbf{6}$ & $\mathbf{7}$ & $\mathbf{8}$ & $\mathbf{9}$ & $\mathbf{1 0}$ & $\mathbf{1 1}$ & $\mathbf{1 2}$ & $\mathbf{1 3}$ \\
\hline Miller, S. 2017 & $\mathrm{V}$ & $\mathrm{V}$ & $\mathrm{V}$ & $\mathrm{V}$ & $\mathrm{V}$ & $\mathrm{V}$ & $\mathrm{V}$ & $\mathrm{V}$ & $\mathrm{V}$ & $\mathrm{V}$ & $\mathrm{V}$ & $\mathrm{V}$ & $\mathrm{V}$ \\
Rosenbek,M. 2011 & $\mathrm{V}$ & $\mathrm{V}$ & $\mathrm{V}$ & $\mathrm{V}$ & $\mathrm{V}$ & $\mathrm{V}$ & $\mathrm{V}$ & $\mathrm{V}$ & $\mathrm{V}$ & $\mathrm{V}$ & $\mathrm{V}$ & $\mathrm{V}$ & $\mathrm{V}$ \\
Dellasega,C. 2012 & $\mathrm{V}$ & $\mathrm{V}$ & $\mathrm{V}$ & $\mathrm{V}$ & $\mathrm{V}$ & $\mathrm{V}$ & $\mathrm{V}$ & $\mathrm{V}$ & $\mathrm{V}$ & $\mathrm{V}$ & $\mathrm{V}$ & $\mathrm{V}$ & $\mathrm{V}$ \\
Chen,S. 2012 & $\mathrm{V}$ & $\mathrm{V}$ & $\mathrm{V}$ & $\mathrm{V}$ & $\mathrm{V}$ & $\mathrm{V}$ & $\mathrm{V}$ & $\mathrm{V}$ & $\mathrm{V}$ & $\mathrm{V}$ & $\mathrm{V}$ & $\mathrm{V}$ & $\mathrm{V}$ \\
Li,M. 2014 & $\mathrm{V}$ & $\mathrm{V}$ & $\mathrm{V}$ & $\mathrm{V}$ & $\mathrm{V}$ & $\mathrm{V}$ & $\mathrm{V}$ & $\mathrm{V}$ & $\mathrm{V}$ & $\mathrm{V}$ & $\mathrm{V}$ & $\mathrm{V}$ & $\mathrm{V}$ \\
Heinrich, E. 2013 & $\mathrm{V}$ & $\mathrm{V}$ & $\mathrm{V}$ & $\mathrm{V}$ & $\mathrm{V}$ & $\mathrm{V}$ & $\mathrm{V}$ & $\mathrm{V}$ & $\mathrm{V}$ & $\mathrm{V}$ & $\mathrm{V}$ & $\mathrm{V}$ & $\mathrm{V}$ \\
Van Eijk, 2011 & $\mathrm{V}$ & $\mathrm{V}$ & $\mathrm{V}$ & $\mathrm{V}$ & $\mathrm{V}$ & $\mathrm{V}$ & $\mathrm{V}$ & $\mathrm{V}$ & $\mathrm{V}$ & $\mathrm{V}$ & $\mathrm{V}$ & $\mathrm{V}$ & $\mathrm{V}$ \\
Welch, G. 2011 & $\mathrm{V}$ & $\mathrm{V}$ & $\mathrm{V}$ & $\mathrm{V}$ & $\mathrm{V}$ & $\mathrm{V}$ & $\mathrm{V}$ & $\mathrm{V}$ & $\mathrm{V}$ & $\mathrm{V}$ & $\mathrm{V}$ & $\mathrm{V}$ & $\mathrm{V}$ \\
Pourisharifa,H. 2013 & $\mathrm{V}$ & $\mathrm{V}$ & $\mathrm{V}$ & $\mathrm{V}$ & $\mathrm{V}$ & $\mathrm{V}$ & $\mathrm{V}$ & $\mathrm{V}$ & $\mathrm{V}$ & $\mathrm{V}$ & $\mathrm{V}$ & $\mathrm{V}$ & $\mathrm{V}$ \\
Styckey,H. 2012 & $\mathrm{V}$ & $\mathrm{V}$ & $\mathrm{V}$ & $\mathrm{V}$ & $\mathrm{V}$ & $\mathrm{V}$ & $\mathrm{V}$ & $\mathrm{V}$ & $\mathrm{V}$ & $\mathrm{V}$ & $\mathrm{V}$ & $\mathrm{V}$ & $\mathrm{V}$ \\
Lakerveld,J. 2013 & $\mathrm{V}$ & $\mathrm{V}$ & $\mathrm{V}$ & $\mathrm{V}$ & $\mathrm{V}$ & $\mathrm{V}$ & $\mathrm{V}$ & $\mathrm{V}$ & $\mathrm{V}$ & $\mathrm{V}$ & $\mathrm{V}$ & $\mathrm{V}$ & $\mathrm{V}$ \\
Rubak,S. 2011 & $\mathrm{V}$ & $\mathrm{V}$ & $\mathrm{V}$ & $\mathrm{V}$ & $\mathrm{V}$ & $\mathrm{V}$ & $\mathrm{V}$ & $\mathrm{V}$ & $\mathrm{V}$ & $\mathrm{V}$ & $\mathrm{V}$ & $\mathrm{V}$ & $\mathrm{V}$ \\
Wonk,M. 2020 & $\mathrm{V}$ & $\mathrm{V}$ & $\mathrm{V}$ & $\mathrm{V}$ & $\mathrm{V}$ & $\mathrm{V}$ & $\mathrm{V}$ & $\mathrm{V}$ & $\mathrm{V}$ & $\mathrm{V}$ & $\mathrm{V}$ & $\mathrm{V}$ & $\mathrm{V}$ \\
Do Valle,N. 2017 & $\mathrm{V}$ & $\mathrm{V}$ & $\mathrm{V}$ & $\mathrm{V}$ & $\mathrm{V}$ & $\mathrm{V}$ & $\mathrm{V}$ & $\mathrm{V}$ & $\mathrm{V}$ & $\mathrm{V}$ & $\mathrm{V}$ & $\mathrm{V}$ & $\mathrm{V}$ \\
Asbjornsdottin, B. 2019 & $\mathrm{V}$ & $\mathrm{V}$ & $\mathrm{V}$ & $\mathrm{V}$ & $\mathrm{V}$ & $\mathrm{V}$ & $\mathrm{V}$ & $\mathrm{V}$ & $\mathrm{V}$ & $\mathrm{V}$ & $\mathrm{V}$ & $\mathrm{V}$ & $\mathrm{V}$ \\
Young,H. 2020 & $\mathrm{V}$ & $\mathrm{V}$ & $\mathrm{V}$ & $\mathrm{V}$ & $\mathrm{V}$ & $\mathrm{V}$ & $\mathrm{V}$ & $\mathrm{V}$ & $\mathrm{V}$ & $\mathrm{V}$ & $\mathrm{V}$ & $\mathrm{V}$ & $\mathrm{V}$ \\
Mikarini,K. 2017 & $\mathrm{V}$ & $\mathrm{V}$ & $\mathrm{V}$ & $\mathrm{V}$ & $\mathrm{V}$ & $\mathrm{V}$ & $\mathrm{V}$ & $\mathrm{V}$ & $\mathrm{V}$ & $\mathrm{V}$ & $\mathrm{V}$ & $\mathrm{V}$ & $\mathrm{V}$ \\
Chollou,K. 2020 & $\mathrm{V}$ & $\mathrm{V}$ & $\mathrm{V}$ & $\mathrm{V}$ & $\mathrm{V}$ & $\mathrm{V}$ & $\mathrm{V}$ & $\mathrm{V}$ & $\mathrm{V}$ & $\mathrm{V}$ & $\mathrm{V}$ & $\mathrm{V}$ & $\mathrm{V}$ \\
Jasink,R. 2013 & $\mathrm{V}$ & $\mathrm{V}$ & $\mathrm{V}$ & $\mathrm{V}$ & $\mathrm{V}$ & $\mathrm{V}$ & $\mathrm{V}$ & $\mathrm{V}$ & $\mathrm{V}$ & $\mathrm{V}$ & $\mathrm{V}$ & $\mathrm{V}$ & $\mathrm{V}$ \\
Zhe,L. 2020 & $\mathrm{V}$ & $\mathrm{V}$ & $\mathrm{V}$ & $\mathrm{V}$ & $\mathrm{V}$ & $\mathrm{V}$ & $\mathrm{V}$ & $\mathrm{V}$ & $\mathrm{V}$ & $\mathrm{V}$ & $\mathrm{V}$ & $\mathrm{V}$ & $\mathrm{V}$ \\
\hline
\end{tabular}

Information:

$\checkmark:$ Yes

$X:$ No

?: Unclear or not applicable

Kriteria Randomized Controlled Clinical Trial

1 : Was true randomization used for assignment of participants to treatment groups?

2 : Was allocation to treatment groups concealed?

3 : Were treatment groups similar at the baseline?

4 : Were participants blind to treatment assignment?

5 : Were those delivering treatment blind to treatment assignment?

6 : Were outcomes assessors blind to treatment assignment?

7 : Were treatment groups treated identically other than the intervention of interest?

8 : Was follow up complete and if not, were differences between groups in terms of their follow up adequately

described and analyzed?

9 : Were participants analyzed in the groups to which they were randomized?

10 : Were outcomes measured in the same way for treatment groups?

11 : Were outcomes measured in a reliable way?

12 : Was appropriate statistical analysis used?

13 : Was the trial design appropriate, and any deviations from the standard RCT design (individual randomization,

parallel groups) accounted for in the conduct and analysis of the trial?

\section{Data Extractions and Synthesis}

A detailed data extraction sheet was used to assist in the data extraction process for studies that fulfilled the inclusion criteria. The main variables extracted were: first author's name, year of publication, study design, number of participants at baseline and follow-up (sample size), eligibility criteria used, intervention delivery method (e.g. individual or group, face-to-face or remote delivery), intervention intensity (number of sessions, duration), health care staff who delivered the intervention and outcomes of the interventions (clinical and psychological measures), quality control (training, supervision, written manuals, and assessments of adherence or competence). 


\section{RESULT}

\section{General Description of Studies}

The process of searching for the articles in this systematic review is carried out according to the PRISMA diagram (figure 1). An initial search using keywords was found 1359 articles. The article was adjusted to the title, then found 379 articles, the article was screened according to the abstracts and found 109 articles, finally, there were 20 complete articles for a systematic review. All articles included in the review and analysis were published between 2011-2020 and are original empirical studies. The main objective of all studies is to examine and assess the effect of motivational interviewing on diabetes mellitus indicators. All of these studies have the same meaning but there are variations in conveying the intervention given, the number of sessions, the length of the session, the outcome indicators to be assessed, and how the effects of the intervention. Based on 20 studies that analyzed $\mathrm{HbA} 1 \mathrm{c}$ measurements and selfmanagement measurements were performed 3 months after the intervention, this time was considered a relatively short time to monitor $\mathrm{HbA} 1 \mathrm{c}$ levels. According to the 20 studies analyzed, the average age of the respondents was 18-77 years old. All of these studies defined people with diabetes mellitus aged 18 years old and over as inclusion criteria and people with severe complications as exclusion criteria. In 20 studies that have been analyzed $\mathrm{HbA1C}$ measurement and selfmanagement conducted measurements 3 months after the intervention, this time is considered a relatively short time to monitor $\mathrm{HbA} 1 \mathrm{c}$ levels. Of the 20 studies analyzed the average age of respondents was $18-77$ years. All of these studies define people with diabetes mellitus aged 18 years and above as inclusion criteria and people with severe complications as exclusion criteria. The document selection is illustrated in Figure 1 and the article summary that fulfills the criteria of a systematic review is shown in Table 3.

\section{Study Characteristics and Evaluation Methods}

The differences in this study are mainly in the key components related to the provision of motivational interviewing such as the method, time, number of sessions required, and the follow-up process to evaluate the study. Three of the 20 studies used educators in the delivery of motivational interviewing interventions. On average, this motivational interviewing is given 2 sessions in one month where each session is given for a minimum of 30 minutes. The evaluation method used in this study is the blood sampling method to determine the results of blood glucose levels to assess $\mathrm{HbA1C}, \mathrm{LDL}, \mathrm{HDL}$, then to determine the results of self-management behavior, self-efficacy, anxiety, medication adherence, and social support using a questionnaire that validated and reliable.

\section{Description of Interventions}

The effect of motivational interviewing intervention was measured in different ways according to the 20 studies. All studies used the $\mathrm{HbA1c}$ indicator to control blood glucose levels. 20 articles consisted of four studies to measure BMI, six studies to measure blood pressure, sixteen studies to

Table 3. Summary of reviewed studies evaluating effect of MI in people with T2DM

\begin{tabular}{|c|c|c|c|c|c|c|c|}
\hline $\begin{array}{l}\text { Name of first } \\
\text { author }\end{array}$ & Design & Sample size & Intervention & Follow up & & Clinical indicators & Results \\
\hline Miller, S (2017) & $\mathrm{RCT}$ & $\begin{array}{l}12 \text { T2DM } \\
\text { patients }\end{array}$ & $\begin{array}{l}\text { Motivational } \\
\text { interviewing } \\
\text { + Medical } \\
\text { Nutrition } \\
\text { Terapy }\end{array}$ & 24 month & $\begin{array}{l}1 . \\
2 . \\
3 . \\
4 . \\
5 .\end{array}$ & $\begin{array}{l}\text { HbA1C } \\
\text { BMI } \\
\text { Systolic blood pressure } \\
\text { Self care management } \\
\text { Dietary self care }\end{array}$ & $\begin{array}{l}\text { The results of the interventions } \\
\text { there was significant differences } \\
\text { between the clinical indicators, } \\
\text { study outcomes HbA1C }<10,25 \% \text {, } \\
\text { BMI }<25 \text {, systolic blood pressure }< \\
142 \text {, self care management and } \\
\text { dietary self care assessment there } \\
\text { was a statistically significant } \\
p=0.001 \text { decrease in the frequency } \\
\text { of fruit and vegetable intake. }\end{array}$ \\
\hline $\begin{array}{l}\text { Rosenbek,M } \\
\text { (2011) }\end{array}$ & $\mathrm{RCT}$ & $\begin{array}{l}178 \text { T2DM } \\
\text { patients }\end{array}$ & $\begin{array}{l}\text { Motivational } \\
\text { interviewing }\end{array}$ & 24 month & $\begin{array}{l}1 . \\
2 . \\
3 .\end{array}$ & $\begin{array}{l}\text { HbA1C } \\
\text { Self efficacy } \\
\text { Diabetes self care }\end{array}$ & $\begin{array}{l}\text { There was no significant difference } \\
\text { score of HbA1C } p=0.221 \text {, self } \\
\text { efficacy } p=0.191 \text { and diabetes self } \\
\text { care } p=0.903\end{array}$ \\
\hline $\begin{array}{l}\text { Dellasega, C } \\
\text { (2012) }\end{array}$ & $\mathrm{RCT}$ & $\begin{array}{l}19 \text { T2DM } \\
\text { patients }\end{array}$ & $\begin{array}{l}\text { Motivational } \\
\text { interviewing }\end{array}$ & 12 month & $\begin{array}{l}1 . \\
2 . \\
3 . \\
4 .\end{array}$ & $\begin{array}{l}\text { HbA1C } \\
\text { Blood pressure } \\
\text { LDL } \\
\text { Self management }\end{array}$ & $\begin{array}{l}\text { There are significant difference in } \\
\text { all clinical indicators, increase } \\
\text { HbA1C, blood pressure, self } \\
\text { management score and LDL } \\
p=0.000\end{array}$ \\
\hline Chen,S (2012) & $\mathrm{RCT}$ & $\begin{array}{l}250 \mathrm{~T} 2 \mathrm{DM} \\
\text { patients }\end{array}$ & $\begin{array}{l}\text { Motivational } \\
\text { interviewing }\end{array}$ & 3 month & $\begin{array}{l}1 . \\
2 . \\
3 . \\
4 .\end{array}$ & $\begin{array}{l}\text { Glycemic outcomes } \\
\text { Self management } \\
\text { Psychological } \\
\text { Quality of life }\end{array}$ & $\begin{array}{l}\text { There are significant difference in } \\
\text { all clinical indicators, self } \\
\text { management } p=0.004 \text {, self efficacy } \\
p=0.0000 \text {, quality of life } p=0.000 \text {. } \\
\text { and } \mathrm{HbA} 1 \mathrm{C} p=0.001\end{array}$ \\
\hline Li,M (2014) & $\mathrm{RCT}$ & $\begin{array}{l}110 \mathrm{~T} 2 \mathrm{DM} \\
\text { patients }\end{array}$ & $\begin{array}{l}\text { Motivational } \\
\text { interviewing }\end{array}$ & 6 month & $\begin{array}{l}1 . \\
2 . \\
3 .\end{array}$ & $\begin{array}{l}\text { Self management } \\
\text { Homeostatic Model } \\
\text { Assessment Insulin } \\
\text { Resistance (HOMA-IR) } \\
\text { HbA1C }\end{array}$ & $\begin{array}{l}\text { Motivational interviewing resulted } \\
\text { in a significant reduction of HbA1C, } \\
\text { HOMA-IR score and diabetes } \\
\text { management }(p=0.000, p=0.001, \\
\text { and } p=0.004)\end{array}$ \\
\hline $\begin{array}{l}\text { Heinrich,E } \\
(2013)\end{array}$ & $\mathrm{RCT}$ & $\begin{array}{l}584 \text { T2DM } \\
\text { patients }\end{array}$ & $\begin{array}{l}\text { Motivational } \\
\text { interviewing }\end{array}$ & 12 month & $\begin{array}{l}1 . \\
2 . \\
3 .\end{array}$ & $\begin{array}{l}\text { HDL } \\
\text { Self efficacy } \\
\text { Blood pressure }\end{array}$ & $\begin{array}{l}\text { There was significant difference in } \\
\text { all clinical indicators HDL } p=0.002 \text {, } \\
\text { self efficacy } p=0.001 \text {, and blood } \\
\text { pressure } 0.000\end{array}$ \\
\hline Van Eijk (2011) & $\mathrm{RCT}$ & $\begin{array}{l}141 \mathrm{~T} 2 \mathrm{DM} \\
\text { patients }\end{array}$ & $\begin{array}{l}\text { Motivational } \\
\text { interviewing }\end{array}$ & 6 month & $\begin{array}{l}1 . \\
2 .\end{array}$ & $\begin{array}{l}\mathrm{HbA1C} \\
\text { BMI }\end{array}$ & $\begin{array}{l}\text { There was significant difference in } \\
\text { all clinical indicators, increase }\end{array}$ \\
\hline
\end{tabular}


Table 3. Summary of reviewed studies evaluating effect of $\mathrm{MI}$ in people with T2DM

\begin{tabular}{|c|c|c|c|c|c|c|}
\hline & & & & & $\begin{array}{l}\text { 3. LDL } \\
\text { 4. Self Care }\end{array}$ & $\begin{array}{l}\text { HbA1C } 7,6 \% \text {, BMI } 2 \% \text {, LDL 2,8\%, } \\
\text { and self efficacy score } p=0.000\end{array}$ \\
\hline Welch,G (2011) & $\mathrm{RCT}$ & $\begin{array}{l}234 \mathrm{~T} 2 \mathrm{DM} \\
\text { patients }\end{array}$ & $\begin{array}{l}\text { Motivational } \\
\text { interviewing } \\
+ \text { DSME }\end{array}$ & 4 month & $\begin{array}{ll}\text { 1. } & \text { HbA1C } \\
\text { 2. BMI } \\
\text { 3. Self management } \\
\text { 4. Social support } \\
\text { 5. Self care }\end{array}$ & $\begin{array}{l}\text { There was significant increase } \\
\text { HbA1C } 1,1, \% \text {, BMI } 15 \% \text {, and self } \\
\text { management, social support, self } \\
\text { care } p=0.000\end{array}$ \\
\hline $\begin{array}{l}\text { Pourisharifa,H. } \\
\text { (2013) }\end{array}$ & $\mathrm{RCT}$ & $\begin{array}{l}93 \text { T2DM } \\
\text { patients }\end{array}$ & $\begin{array}{l}\text { Motivational } \\
\text { interviewing } \\
+ \text { CBGT }\end{array}$ & 12 month & $\begin{array}{ll}\text { 1. } & \mathrm{BMI} \\
\text { 2. } & \mathrm{HbA} 1 \mathrm{C}\end{array}$ & $\begin{array}{l}\text { The research result show that } \\
\text { motivational interviewing }+ \text { CBGT } \\
\text { can improve the } \mathrm{BMI} \text { and } \mathrm{HbA} 1 \mathrm{C} \mathrm{p}\end{array}$ \\
\hline Stuckey,H (2013) & $\mathrm{RCT}$ & $\begin{array}{l}549 \text { T2DM } \\
\text { patients }\end{array}$ & $\begin{array}{l}\text { Motivational } \\
\text { interviewing }\end{array}$ & 12 month & $\begin{array}{ll}\text { 1. } & \mathrm{HbA} 1 \mathrm{C} \\
\text { 2. } & \mathrm{LDL} \\
\text { 3. } & \text { Blood Pressure }\end{array}$ & $\begin{array}{l}\text { There was significant difference in } \\
\text { all clinical indicator, patient had } \\
\text { elevated HbA1C } 8,4 \text {, BP } 133 / 77 \\
\text { and LDL } 114\end{array}$ \\
\hline $\begin{array}{l}\text { Lakerveld,J. } \\
\text { (2013) }\end{array}$ & $\mathrm{RCT}$ & $\begin{array}{l}314 \text { T2DM } \\
\text { patients }\end{array}$ & $\begin{array}{l}\text { Motivational } \\
\text { interviewing }\end{array}$ & 12 month & $\begin{array}{l}\text { 1. HbA1C } \\
\text { 2. Blood pressure } \\
\text { 3. Self care management }\end{array}$ & $\begin{array}{l}\text { There was significant between } \\
\text { HbA1C, blood pressure and self } \\
\text { care management (mean } 8,9 \% \text {, } \\
9,9 \% \text { and } 8 \% \text { ). }\end{array}$ \\
\hline Rubak,S (2011) & $\mathrm{RCT}$ & $\begin{array}{l}80 \mathrm{~T} 2 \mathrm{DM} \\
\text { patients }\end{array}$ & $\begin{array}{l}\text { Motivational } \\
\text { interviewing }\end{array}$ & 6 month & $\begin{array}{l}\text { 1. HbA1C } \\
\text { 2. Medication adherence } \\
\text { 3. Self management } \\
\text { 4. Quality of life }\end{array}$ & $\begin{array}{l}\text { There was significant, medication } \\
\text { adherence score } 100 \%, \mathrm{HbA} 1 \mathrm{C} \\
\mathrm{p}=0.001 \text {, self management and } \\
\text { quality of life } p=0.002\end{array}$ \\
\hline Wonk,M (2020) & $\mathrm{RCT}$ & $\begin{array}{l}25 \text { T2DM } \\
\text { patients }\end{array}$ & $\begin{array}{l}\text { Motivational } \\
\text { interviewing }\end{array}$ & 6 month & $\begin{array}{l}\text { 1. Blood pressure } \\
\text { 2. BMI } \\
\text { 3. Psychosocial } \\
\text { 4. Self care management }\end{array}$ & $\begin{array}{l}\text { There was significant between } \\
\text { blood pressure and BMI } p=0.001 \text {. } \\
\text { the effect size for the primary } \\
\text { outcomes HbA1C is } 0,32 \% \text {. The } \\
\text { result Motivational interviewing } \\
\text { approach helps in overall diabetic } \\
\text { care. }\end{array}$ \\
\hline $\begin{array}{l}\text { Do Valle,N } \\
(2017)\end{array}$ & $\mathrm{RCT}$ & $\begin{array}{l}57 \text { T2DM } \\
\text { patients }\end{array}$ & $\begin{array}{l}\text { Motivational } \\
\text { interviewing }\end{array}$ & 6 month & $\begin{array}{l}\text { 1. Quality of life } \\
\text { 2. Physical activity } \\
\text { 3. Medication adherence } \\
\text { 4. HbA1C } \\
\text { 5. LDL }\end{array}$ & $\begin{array}{l}\text { The result was significan between } \\
\text { motivational interviewing and } \\
\text { quality of life }(p=0.001) \text {, physical } \\
\text { activity }(p=0.001) \text {, medication } \\
\text { adherence }(p=0.002) \text {, HbA1C level } \\
0,34 \% \text { point lower than at baseline, } \\
\text { LDL }(p=0.004) \text {. }\end{array}$ \\
\hline $\begin{array}{l}\text { Asbjornsdottin, B } \\
\text { (2019) }\end{array}$ & $\mathrm{RCT}$ & $\begin{array}{l}22 \mathrm{~T} 2 \mathrm{DM} \\
\text { patients }\end{array}$ & $\begin{array}{l}\text { Motivational } \\
\text { interviewing }\end{array}$ & 6 month & $\begin{array}{l}\text { 1. } \mathrm{HbA1C} \\
\text { 2. BMI }\end{array}$ & $\begin{array}{l}\text { The result was significan between } \\
\text { motivational interviewing and } \\
\text { HbA1C }(p=0.001), B M I(p=0.000)\end{array}$ \\
\hline Young,H (2020) & $\mathrm{RCT}$ & $\begin{array}{l}319 \text { T2DM } \\
\text { patients }\end{array}$ & $\begin{array}{l}\text { Motivational } \\
\text { interviewing } \\
+\mathrm{mHealth}\end{array}$ & 3 month & $\begin{array}{ll}\text { 1. } & \text { Self efficacy } \\
\text { 2. Psycal activity } \\
\text { 3. HbA1c }\end{array}$ & $\begin{array}{l}\text { There was significant self efficacy } \\
\text { score } p=0.001 \text {, psycal activity } \\
\text { increase form } 39,16 \text { to } 32,61 \text { and } \\
\text { HbA1C } p=0.002\end{array}$ \\
\hline $\begin{array}{l}\text { Mikarimi,K } \\
\text { (2017) }\end{array}$ & RCT & $\begin{array}{l}100 \mathrm{~T} 2 \mathrm{DM} \\
\text { patients }\end{array}$ & $\begin{array}{l}\text { Motivational } \\
\text { interviewing }\end{array}$ & 6 month & $\begin{array}{l}\text { 1. Weight efficacy lifestyle } \\
\text { 2. Social pressure } \\
\text { 3. Self management } \\
\text { 4. Glycemic control }\end{array}$ & $\begin{array}{l}\text { The result was significan between } \\
\text { motivational interviewing and } \\
\text { weigh efficacy life style } p=0.001 \text {, } \\
\text { social pressure } p=0.001, \quad \text { self } \\
\text { management } p=0.001, \quad \text { and } \\
\text { glycemic control } p=0.001\end{array}$ \\
\hline Collou,K (2020) & $\mathrm{RCT}$ & $\begin{array}{l}192 \mathrm{~T} 2 \mathrm{DM} \\
\text { patients }\end{array}$ & $\begin{array}{l}\text { Motivational } \\
\text { interviewing } \\
\text { +Health } \\
\text { Literacy }\end{array}$ & 6 month & $\begin{array}{l}\text { 1. } \mathrm{HbA} 1 \mathrm{C} \\
\text { 2. Self care behavior }\end{array}$ & $\begin{array}{l}\text { The result was significan between } \\
\text { motivational interviewing and } \\
\text { HbA1c } p=0.000 \text { and self care } \\
\text { behavior } p=0.002\end{array}$ \\
\hline Jasink, R (2013) & $\mathrm{RCT}$ & $\begin{array}{l}35 \text { T2DM } \\
\text { patients }\end{array}$ & $\begin{array}{l}\text { Motivational } \\
\text { interviewing }\end{array}$ & 14 month & $\begin{array}{l}\text { 1. Self management } \\
\text { 2. Behavior } \\
\text { 3. Lifestyle }\end{array}$ & $\begin{array}{l}\text { The result was significan between } \\
\text { motivational interviewing and self } \\
\text { management } p=0.000 \text {, behavior } \\
\text { score } p=0.001 \text { mean difference } \\
0.39 \text {, lifestyle score } p=0.032 \text { mean } \\
\text { difference } 0.28\end{array}$ \\
\hline Ribu,L (2013) & $\mathrm{RCT}$ & $\begin{array}{l}225 \mathrm{~T} 2 \mathrm{DM} \\
\text { patients }\end{array}$ & $\begin{array}{l}\text { Motivational } \\
\text { interviewing }\end{array}$ & 3 month & $\begin{array}{l}\text { 1. Medication adherence } \\
\text { 2. HbA1C } \\
\text { 3. Self Management }\end{array}$ & $\begin{array}{l}\text { Motivational interviewing was } \\
\text { significant effect on improving } \\
\text { medication adherence, } \mathrm{HbA} 1 \mathrm{C} \text {, and } \\
\text { self management } \mathrm{p}=0.001\end{array}$ \\
\hline
\end{tabular}

measure seif-management, four studies to measure seifefficacy, five studies to measure HDL \& LDL, two studies to measure social support, three studies to measure medication adherence, three studies to measure psychosocial, and five studies to measure the quality of life.

Effect Motivational Interviewing on Glycosylated

\section{Hemogiobin (Hba1c)}

According to the 20 studies that have been analyzed, 19 studies have shown that there is an effect of motivational interviewing on $\mathrm{HbA} 1 \mathrm{C}$ levels, the results show that the average $\mathrm{HbA} 1 \mathrm{C}$ value is significant and in the range of less than $6.4 \%$. There is one study that states that the results of the research are not significant with a $p$-value $=0.221$, in 
this study it is not explained about the change in the average $\mathrm{HbA} 1 \mathrm{C}$.

\section{Effect of Motivational Interviewing on Self Management}

In the study that has been described, 16 studies state that motivational interviewing is effective for improving patient self-management. The components of selfmanagement that are measured in this study are medication adherence, self-efficacy, BMI, blood pressure, and quality of life. There was a specific increase in medication adherence and self-efficacy, in addition to BMI and blood pressure, significant results were obtained with averages within the normal limits of BMI and blood pressure.

\section{DISCUSSION}

Motivational interviewing is a new counseling method that was developed as a basis for counseling and education. This systematic review shows that motivational interviewing is very influential on several indicators in diabetes care management (13). The very influential thing is the change in $\mathrm{HbA} 1 \mathrm{C}$ levels. In giving the motivational interviewing intervention, it was able to control HbA1C levels because the method of giving this intervention involved the patient in decision making. Thus, patients are more regular in self-management, especially adherence to taking medication. This is the basis for control HbA1C levels (14).

One of the important elements needed to support the activities of people with diabetes mellitus is a source of information. Accurate and fast information about health and techniques to maintain health is very important for patients with diabetes mellitus (15). In this motivational interviewing method, providing education including diet patterns, activity patterns, and maintaining patient selfcare has been designed to increase productivity and quality of life for people with diabetes mellitus type 2 (16).

Motivational interviewing can affect self-management, psychosocial, and quality of life because motivational interviewing can manage stress experienced by diabetes mellitus patients because this stress can result in impaired blood glucose control caused by excess cortisol production, a hormone that reduces the body's sensitivity to insulin. This causes the glucose in the blood to increase (17). A person experiencing a problem needs to identify and study the problem. Providing motivational interviewing counseling will provide additional information in the form of education in the form of knowledge about diabetes mellitus (18). Knowledge gives a feeling of having control within a person to solve problems and deal with sources of stressors. Motivational interviewing can change the ambivalence that exists in patients with diabetes mellitus and will increase existing knowledge, thus it will improve patient self-management (19).

Motivational interviewing will encourage actions taken by someone that comes from his mind. Self-efficacy is significantly positively related to diabetes management behavior in people with diabetes type 2 . These behaviors

\section{REFERENCES}

1. Pourisharif $H$, Babapour J, Zamani R, Besharat MA, Mehryar AH, and Rajab A. The Effectiveness of Motivational Interviewing in Improving Health include a healthy diet, physical activity, self-monitoring of blood glucose, drug therapy, and foot care (20). High selfefficacy, good social support, and effective problemsolving skills in diabetes mellitus type 2 patients are known to be more prepared to cope with life's stresses and improve self-management. Self-efficacy has an important role in increasing the self-care behavior of each respondent. Self-efficacy in the respondent's ability to regulate or demonstrate existing behavior as a goal to be achieved (21).

Motivational interviewing can affect medication adherence and glycemic outcomes of patients with diabetes mellitus because it patient center care collaborative guidance to obtain and strengthen motivation that works through ambivalence $(2,14)$. The influence of this motivational interviewing intervention is because the key strategies implemented to develop differences and increase commitment to compliance include: asking the patient's permission before sharing information, listening reflectively, using open-ended questions, providing reflection, and giving affirmations. Motivational interviewing is effective in changing health behavior, especially in medication adherence in patients with diabetes mellitus type 2 (18).

The studies analyzed in this systematic review showed that one of the strategies to improve compliance patients was by using the psychological intervention, namely motivational interviewing. This method can improve the patient's behavior change in terms of complying with selfmanagement. Even though not all studies resulted in a significant value at all aspects of the measurement parameter, however, the conclusion could be drawn based on the parameter of self-management in diabetes mellitus patients $(1,4)$. The psychological intervention was effective in increasing a certain outcome in type $2 \mathrm{DM}$ patients. The psychological intervention, even, could control blood glucose levels. The glycemic control can be achieved due to the increased patient compliance in self-management. Sampling in selecting the intervention also needed to be concerned in determining the sample age. The extreme estimated age will influence the activity and glucose metabolism in type 2 DM patients. This was conducted for maintaining the homogeneity of research samples (8).

This systematic review concludes that motivational interviewing positively influences the self-management of diabetes mellitus patients. This motivational interviewing result can change the patients behavior through the patient centered intervention technique that involves patients in decision-making. This result can improve the patients understanding related to self-management in changing behavior. The collected result also shows that it can make patients' glycemic control better,thus it can improve the life quality of patients with type 2 diabetes mellitus.

\section{ACKNOWLEDGEMENTS}

The authors would like to thank Hannah translation for language editing of the manuscript.

Outcomes in Adults with Type 2 Diabetes. Procedia Social and Behavioral Sciences. 2013; 5: 1580-1584.

2. Miller S and Akohoue S. Two-Year Follow-Up Study of a Group-Based Diabetes Medical Nutrition Therapy 
and Motivational Interviewing Intervention among African American Women. Patient Related Outcome Measures. 2017; 8:57-61.

3. Jansink R, Braspenning J, Laurant M, et al. Minimal Improvement of Nurses' Motivational Interviewing Skills in Routine Diabetes Care One Year After Training: A Cluster Randomized Trial. BMC Family Practice. 2013; 14: 1-10.

4. Minet LKR, Wagner L, Lønvig EM, Hjelmborg J, and Henriksen JE. The Effect of Motivational Interviewing on Glycaemic Control and Perceived Competence of Diabetes Self-Management in Patients with Type 1 and Type 2 Diabetes Mellitus After Attending a Group Education Programme: A Randomised Controlled Trial. Diabetologia. 2011; 54(7): 1620-1629.

5. Rubak S, Sandbæk A, Lauritzen T, Borch-Johnsen K, and Christensen B. Effect of "Motivational Interviewing" on Quality of Care Measures in Screen Detected Type 2 Diabetes Patients: A One-Year Follow-Up of an RCT, ADDITION Denmark. Scandinavian Journal of Primary Health Care. 2011; 29(2): 92-98.

6. Heinrich E, Candel MJJM, Schaper NC, and de Vries NK. Effect Evaluation of a Motivational Interviewing Based Counselling Strategy in Diabetes Care. Diabetes Research and Clinical Practice. 2010; 90(3): 270-278.

7. Dellasega C, Añel-Tiangco RM, and Gabbay RA. How Patients with Type 2 Diabetes Mellitus Respond to Motivational Interviewing. Diabetes Research and Clinical Practice. 2012; 95(1): 37-41.

8. Li M, Li T, Shi BY, and Gao CX. Impact of Motivational Interviewing on the Quality of Life and Its Related Factors in Type 2 Diabetes Mellitus Patients with Poor Long-Term Glycemic Control. International Journal of Nursing Science. 2014; 1(3): 250-254.

9. Chen SM, Creedy D, Lin HS, and Wollin J. Effects of Motivational Interviewing Intervention on SelfManagement, Psychological and Glycemic Outcomes in Type 2 Diabetes: A Randomized Controlled Trial. International Journal of Nursing Studies. 2012; 49(6): 637-644.

10. Welch G, Zagarins SE, Feinberg RG, and Garb JL. Motivational Interviewing Delivered by Diabetes Educators: Does it Improve Blood Glucose Control among Poorly Controlled Type 2 Diabetes Patients? Diabetes Research and Clinical Practice. 2011; 91(1): 54-60.

11. Van Eijk-Hustings YJL, Daemen L, Schaper NC, Vrijhoef HJM. Implementation of Motivational Interviewing in a Diabetes Care Management Initiative in the Netherlands. Patient Education and Counseling. 2011; 84(1): 10-15.

12. Lakerveld J, Bot SD, Chinapaw MJ, et al. Motivational Interviewing and Problem Solving Treatment to Reduce Type 2 Diabetes and Cardiovascular Disease Risk in Real Life: A Randomized Controlled Trial. The
International Journal of Behavioral Nutrition and Physical Activity. 2013; 10: 1-10.

13. Stuckey HL, Dellasega C, Graber NJ, Mauger DT, Lendel I, and Gabbay RA. Diabetes Nurse Case Management and Motivational Interviewing for Change (DYNAMIC): Study Design and Baseline Characteristics in the Chronic Care Model for Type 2 Diabetes. Contemporary Clinical Trials. 2013; 30(4): 366-374.

14. Wong MK, Cheng SYR, Chu TK, et al. Impact of Motivational Interviewing on Self-Management in Patients with Type 2 Diabetes: Protocol for a Pilot Randomized Controlled Trial. Journal of Medical Internet Research, Research Protocols. 2020; 9(3): 1-10.

15. Nascimento TMRV, Resnicow K, Nery M, Brentani A, Kaselitz E, Agrawal P, et al. A Pilot Study of a Community Health Agent-Led Type 2 Diabetes SelfManagement Program Using Motivational Interviewing-Based Approaches in a Public Primary Care Center in São Paulo, Brazil. BMC Health Service Research. 2017; 17(1): 1-10.

16. Ásbjörnsdóttir $B$, Vestgaard $M$, Ringholm $L$, et al. Effect of Motivational Interviewing on Gestational Weight Gain and Fetal Growth in Pregnant Women with Type 2 Diabetes. BMJ Open Diabetes Research \& Care. 2019; 7(1): 1-9.

17. Young HM, Miyamoto S, Dharmar M, and TangFeldman Y. Nurse Coaching and Mobile Health Compared with Motivational Interviewing to Improve Diabetes Self-Efficacy for Persons with Type 2 Diabetes: Randomized Controlled Trial. JMIR mHealth uHealth. 2020; 8(3).

18. Mirkarimi K, Kabir MJ, Honarvar MR, Ozouni-Davaji $\mathrm{RB}$, and Eri M. Effect of Motivational Interviewing on Weight Efficacy Lifestyle among Women with Overweight and Obesity: A Randomized Controlled Trial. Iranian Journal of Medical Sciences. 2017; 42(2): 187-193.

19. Chollou KM, Gaffari-Fam S, Babazadeh T, Daemi A, Bahadori A, and Heidari S. The Association of Health Literacy Level with Self-Care Behaviors and Glycemic Control in a Low Education Population with Type 2 Diabetes Mellitus: A Cross-Sectional Study in Iran. Diabetes, Metabolic Syndrome and Obesity: Targets and Theraphy. 2020; 13: 1685-1693.

20. Ribu L, Holmen H, Torbjørnsen A, et al. Low-Intensity Self-Management Intervention for Persons with Type 2 Diabetes Using a Mobile Phone-Based Diabetes Diary, With and Without Health Counseling and Motivational Interviewing: Protocol for a Randomized Controlled Trial. JMIR Research Protocols. 2013; 2(2): 1-14.

21. Dean S, Britt E, Bell E, Stanley J, and Collings S. Motivational Interviewing to Enhance Adolescent Mental Health Treatment Engagement for Persons with Type 2 Diabetes: A Randomized Clinical Trial. Psychological Medicine. 2016; 46(9): 1961-1969. 